
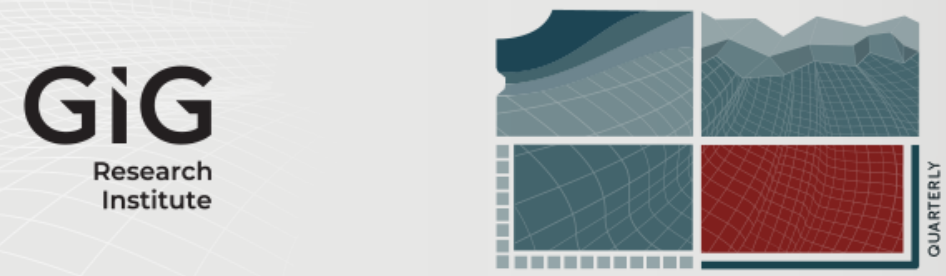

\title{
JOURNAL OF SUSTAINABLE MINING
}

\section{In search of a future for mining: participative scenarios for Colombia}

Author(s) ORCID Identifier:

Santiago Arango-Aramburo (iD) 0000-0002-5009-0986

Ricardo Smith (iD) 0000-0002-0888-7596

Patricia Jaramillo (iD) 0000-0001-9007-4326

Yris Olaya (iD) 0000-0001-5210-4731

Adrian Saldarriaga (iD) 0000-0002-3064-5251

Oscar J. Restrepo (iD) 0000-0003-3944-9369

Sebastian Bernal (iD 0000-0001-6598-1995

Erik R. Larsen (iD 0000-0002-5718-4221

Follow this and additional works at: https://jsm.gig.eu/journal-of-sustainable-mining

Part of the Explosives Engineering Commons, Oil, Gas, and Energy Commons, and the Sustainability Commons

\section{Recommended Citation}

Arango-Aramburo, Santiago; Smith, Ricardo; Jaramillo, Patricia; Olaya, Yris; Saldarriaga, Adrian; Restrepo, Oscar J.; Arboleda, Yuly; Rua, Carla; Bernal, Sebastian; Londono, Pablo E.; and Larsen, Erik R. (2020) "In search of a future for mining: participative scenarios for Colombia," Journal of Sustainable Mining: Vol. 19 : Iss. 2 , Article 2.

Available at: https://doi.org/10.46873/2300-3960.1007

This Research Article is brought to you for free and open access by Journal of Sustainable Mining. It has been accepted for inclusion in Journal of Sustainable Mining by an authorized editor of Journal of Sustainable Mining. 


\title{
In search of a future for mining: participative scenarios for Colombia
}

\begin{abstract}
We describe and discuss the development of scenarios for the Colombian mining industry. The scenarios were developed with a large group of stakeholders from across the Colombian government, society, and commerce, all with interest in and/or affected by the future of the mining sector. The process resulted in the creation of three different scenarios for the Colombian mining sector to 2030 . The article describes the participatory process used for involving the stakeholders, including the workshops and the mapping technique that was used. It also outlines the three scenarios and possible policies that should be considered by the Colombian government in order to prepare the sector for the future.
\end{abstract}

\section{Keywords}

Mining; Scenario process; Participatory scenario development; Mining policy

\section{Creative Commons License}

\section{(c) (7)}

This work is licensed under a Creative Commons Attribution 4.0 License.

\section{Authors}

Santiago Arango-Aramburo, Ricardo Smith, Patricia Jaramillo, Yris Olaya, Adrian Saldarriaga, Oscar J. Restrepo, Yuly Arboleda, Carla Rua, Sebastian Bernal, Pablo E. Londono, and Erik R. Larsen 


\title{
In Search of a Future for Mining: Participative Scenarios for Colombia
}

\author{
Santiago Arango-Aramburo a,*, Ricardo Smith a , Patricia Jaramillo a , Yris Olaya a, \\ Adrian Saldarriaga a , Oscar J. Restrepo a , Yuly Arboleda a, Carla Rua b , Sebastian Bernal ${ }^{\text {a }}$, \\ Pablo E. Londono ${ }^{a}$, Erik R. Larsen ${ }^{\mathrm{c}}$ \\ a Universidad Nacional de Colombia, Sede Medellín, Faculty of Mines, Decision Sciences Group, Carrera 80 No 65-223 Bloque M8a, \\ 050041, Medellín, Colombia \\ ${ }^{\mathrm{b}}$ Università della Svizzera italiana, Institute of Management and Organization, Via G. Buffi 13, CH-6904, Lugano, Switzerland \\ ${ }^{c}$ Aarhus University, Department of Management, Fuglesangs Allé 4, DK8219, Aarhus V, Denmark
}

\begin{abstract}
We describe and discuss the development of scenarios for the Colombian mining industry. The scenarios were developed with a large group of stakeholders from across the Colombian government, society, and commerce, all with interest in and/or affected by the future of the mining sector. The process resulted in the creation of three different scenarios for the Colombian mining sector to 2030. The article describes the participatory process used for involving the stakeholders, including the workshops and the mapping technique that was used. It also outlines the three scenarios and possible policies that should be considered by the Colombian government in order to prepare the sector for the future.
\end{abstract}

Keywords: mining, scenario process, participatory scenario development, mining policy

\section{Introduction}

$\mathrm{T}$ he mining sector has long been an important, and in many cases and countries, a controversial sector. There is no doubt about the economic impact of the sector, which for many countries makes significant contributions to their economy, directly, through taxes paid to the government and indirectly, in the form of employment and ancillary services. Mining plays an important role in the economy of developed countries such as Australia and Canada, while developing countries such as Angola and Congo economies are more dependent on demand and price of raw materials [1].

Mining has also created many environmental as well as social problems. The environmental problems include, among others, pollution of rivers [2], of underground drinking water [3], droughts resulting from water being used in extraction [4], and various health problems following from mining [5]. In many cases, these problems have created local as well as national and global protests from environmental activists [6], who claim that some areas are too sensitive for mining, or that regulations have not been followed [7]. Social conflicts with local communities arise, for example, when communities feel that they do not get any share of the wealth from the mine [8]. Other conflicts occur between farmers and mining companies over land and water use [9].

Given the interaction of economic, environmental, and social factors, mining becomes a complex and complicated issue. Add to this the often large fluctuations of the price of raw materials resulting in significant fluctuations in the price of dependent products, e.g. copper price fell by more than 50 percent from 2011 to 2016 [10]. Furthermore, mining has been associated for many years with corruption, 
political instability, and international political deals [11]. Taking all these dimensions of mining together makes the management of an individual project, as well as regional and national planning, a very uncertain and potentially contentious issue.

In the project described here, we look at the future prospect of the mining sector in Colombia. The question posed as a basis for the project was: "What might be the future of the mining sector in Colombia?" The mining sector in Colombia is important to the economy, although not to the same degree as in other South American countries such as Chile. In Colombia, the sector counts for around 2.3 percent of GDP [12].

The project described here was started at the request of the planning office, Unidad de Planeación Minero Energética (UPME), of the Ministry for Energy and Mining. UPME were interested in getting a better understanding of the possible development of the mining sector in Colombia. This included the economic, social and environmental evolution under a range of different sets of (possible) national and global growth paths. The aim is to understand and test which set of mining policies might provide the best outcome across a range of scenarios while also anticipating the possible negative side-effects that such an optimal set of policies might have for each of the different scenarios.

The paper is organized in the following way. We begin with a brief overview of mining in Colombia to highlight the general and specific characteristics of the sector. We discuss the methodology that we used and the organization of the process, including the content of the workshops there was part of the project. Next we discuss the scenarios developed using the process. We continue with a discussion of the implications for the Colombian mining sector and ends with a conclusion.

\section{Mining in Colombia}

There has long been a mining industry in Colombia; however, it has never achieved the same dimensions and importance as in some of the neighboring countries, and the sector plays only a minor role in global mineral markets. Within the Colombian mining sector, coal is the only mineral produced on a large scale, accounting for around 70 percent of the domestic mining sector revenue. As shown in Fig. 1, the production of coal almost doubled in the decade from 2000.

The other two main mineral products are nickel (for ferronickel production) and gold, accounting for most of the remaining revenue from the mining sector. There are further small productions of, among others: silver, emeralds, and platinum [13]. Additionally, there is mining for building materials, mainly for domestic markets, but providing little revenue for the extraction companies and almost no royalties for the government. In the first decade of this century, mineral prices had been relatively high compared to historical averages. This also lead to the highest collection of royalties in history; however, the years since have resulted in a downward trend.

Despite the political and economic stability of Colombia, the relatively high price for raw materials for a decade, and the efforts to attract investment by improving the quality of mining information and institutions, no important big new mines have been opened over the last twenty years. A reorganization of the government institutions for the mining sector took place in 2010 but these institutions are still perceived by many investors as weak, uncoordinated, and lacking in clear policies for the sector [14].

There are still many unresolved conflicts within the Colombian mining sector. This includes disagreements between local authorities responsible for territorial planning, local communities, and the central government bodies responsible for environmental and fiscal planning. Among the specific issues are disputes over land use and compensation, allocation of revenues, influence of the local communities, and environmental issues [15]. A further complication is informal mining that has no operation permit. As there is no regulation and oversight, informal mining generally follows bad environmental practices, paying no attention to miners' safety, the environment, or the livelihoods of surrounding and downstream communities, among other negative impacts. On the other hand, the informal sector also provides employment and income for many families in areas where they would otherwise be unable to find employment $[16,17]$.

One consequence of these unresolved issues is that a large part of the Colombian public sees mining as a polluting activity. They believe, that it contributes more to corruption and environmental degradation than to the nation's development, reinforcing the view that mining is not an attractive industry for investment.

We consider the mining section in Colombia as whole, i.e. the range from large-scale mineral exploitation to artisanal small mining, including illegal mining. Large-scale mines are normally operated by multinational mining firms as direct 


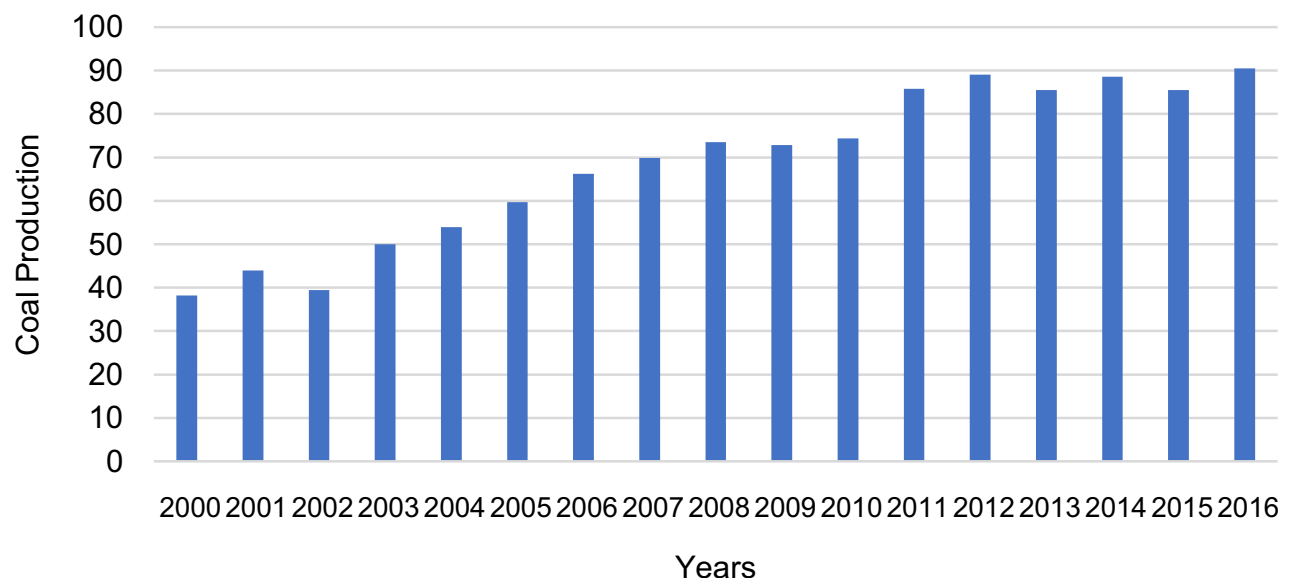

Fig. 1. The evolution of coal production in Colombia (in millions of tons).

foreign investment, while artisanal miners are mostly occupied with the extraction of gold using methods [18]. The sector operates at different scales simultaneously. There are, literally, unauthorized miners operating inside large-scale mines. The policies to attract foreign investment in large-scale project, have often created disputes with and disruption for artisanal mining [19,20].

This situation of simultaneous co-existing of large-scale, artisanal and illegal mining creates a complex problem with no easy solutions. Scenarios analysis is a useful tool to help mapping-out and make sense of this set of entangled issues, that cover from environmental issues, local involvement, profitability and macro-economic considerations just to mention a few. There is a consensus that the government should legalize and formalize artisanal mining. However, this requires a sector-specific legislation in a sector that traditionally has focused policies on stimulus for foreign investments in large-scale mining. Little attention has been given to artisanal mining which, due to its scale do not have the same macro-economic effects [18]. It is important to note that artisanal miners will not stop, and they will find ways to continue with the activity as long as their survival depends on it [21]. The problem is further complicated with the participation of illegal armed groups in particular gold extraction, as a form for money laundry, territorial control and other criminal activities [18]. Illegal mining is not a unique Colombian problem it takes place in many other jurisdictions where regulation and enforcement is not strong enough to prevent it, examples includes Asia (e.g. [22], Africa (e.g. [23], and other Latin American countries (e.g. [24].

\section{Methodology}

There are a number of different methods for beginning to understand a complex issue like the future of mining in Colombia, ranging from economic forecasting, through political analysis to Delphi methods. Mining in Colombia has a number of complex and often interdependent issues such as:

- The large degree of uncertainty associated with the mining sector, especially when the aim is to take a long-term view. There are uncertainties on demand and prices, as well as in requirements for environmental and social conditions, which can be influenced by both internal (national) requirements as well as by international demands.

- Short- and long-term tradeoffs, e.g. raising government revenue from mining versus the long-term environmental impact, the employment possibilities for local communities versus the possibilities after mining ends.

- Many stakeholders with diverse, and at times opposing, interest and focus e.g. local activists, local communities, environmentalist, governments, private and public mining companies etc.

There has for a long period been discussions in the foresight community how best to deal with situations like these. How to get diverse groups of organizations to reach a shared understanding of the problems and potential opportunities. Scenarios has been shown to be one of the methods that can deal with the characteristics of the Colombian mining sector. Scenarios has been used to deal with multiple stakeholders, e.g. in the case of 
understanding skills in the building sector [25], scenarios for the Brazilian Amazon [26].

As the characteristics of the Colombian mining issues are well aligned with the reason for using scenarios discussed above was scenarios chosen as the method in thie case. Scenarios support

- The possibility exists for involving a large number and diverse range of stakeholders, including public and private organization, as well as NGOs and academics as mention above.

- It is possible to include a large amount of data and take account of a wide range of expectations in the discussion, making it an open project without prejudging the mining industry's evolving directions.

- A scenario approach provides the ability to deal with the effect of large investments, long startup lags, long-term production, and social and environmental impacts.

Scenario methods are able to deal with all these concerns, particularly the great uncertainty that characterizes the sector. While there are different definitions of scenarios, they all develop a set of future possible worlds. The starting point being that it is impossible to predict the future, so the unit of analysis (e.g. organization, country etc.) needs to be able to be sustainable in a variety of different possible futures. When the scenarios are developed, they are used to verify the robustness and suitability of various strategies and policies relevant in the specific situation.We see scenarios, in the context it is used here, as a clear description of conceivable futures in line with [27]. Our approach here belongs to what is sometimes known as the intuitive logics school [28].

Scenarios have been used since the Sixties as a way of helping private and public organizations to understand the long-term development of both small and large issues where the uncertainty has been too big to use more traditional forecasting $[29,30]$. They have been used to help create understanding on a diverse set of issues, including but not limited to: global warming and sustainability [31]: [32], countries, e.g. the future of South Africa [33], public sectors such as teaching and learning [34,35], and industrial sectors such as wind and photo voltics [36-38]. They are also used by organizations such as Shell [39], as well as NGOs such as [40].

Scenarios have been used in the areas of energy and of raw materials and mining, at least since Shell introduced them into their planning process in the late Sixties [29]. Recent examples include the energy sector in Colombia [41], where scenarios were used to evaluate the future of the electricity sector. Due to the inherent uncertainty in most mining projects, scenarios have been used for a long time in the mining industry too (e.g. [42-44].

It has been claimed that there is no single way to generate scenarios [28]. Our aim in this paper is to focused on a scenario approach that enable as diverse and broad an involvement of the stakeholders as possible. We used a variety of methods from the scenarios literature, including secondary material, interviews [45], interactive workshops [46], causal mapping [37] and expert-panels[47].

A scenario process has (often) two general parts: the development of the scenarios, followed by the use of these scenarios for testing and developing new strategies and policies. In this paper, we are only concerned with the development of the scenarios. That is getting to the stage where we have a set of possible worlds representing different directions in which the mining sector in Colombia evolve over the next two decades. The actual use of these scenariosis outside the scope of this paper.

\subsection{Stakeholders in the scenario development process}

The convoluted issues that characterize the minerals sector in Colombia requires the collaboration of academic scientific/technical, mining professionals/experts and government sector representatives. There is abundant evidence that to solve complex problems one need to involve the central stakeholders, e.g. in preparing for climate change [48], Sustainability [49], and mining [50].

The project management considered and consulted on which groups of stakeholders were essential for the success of the scenario project. The stakeholders were after the discussions been thought off as four groups: A coordination group in charge of the project planning and execution. This group included members from the decision-making group of the Universidad Nacional de Colombia (UNAL), the UPME and national and international consultants. The second group was a support group of experts, whose main purpose was to provide technical insight, access to information and general technical knowledge on mining. This group consisted of participants such as professors from different departments of UNAL, e.g.the Department of Geosciences and Environment, and the Department of Materials and Minerals. The third group was the largest, an interdisciplinary group representing the different stakeholders in the Colombian mining sector. This group included, among others, private-sector mining experts, 
managers from the private sector, environmentalists, government officials, academics, and consultants. The final group, called Oracle, supported and validated all project findings. In total, more than 100 people were involved in the project. The total duration of the project was eight months, in which the first three months involved setting up and performing the interviews; running the workshops took an additional four months. Appendix 1 list the organizations and institutions from where the participants came; all the participants had knowledge of the Colombian or international mining sector.

\subsection{Activities in the scenario development process}

The process that we followed for the development of the scenarios can be seen in terms of three workshops with the stakeholders and additional meetings with the expert and coordination group. The process is outlined in Table 1 and discussed in more detail below. The project, including the workshops, interviews and writing of the results, took place over a six months period.

\subsubsection{Collecting information from literature and interviews}

The initially task was to create an overview of the current state of the Colombian mining sector. This was done through secondary sources, including information from official sources, available information from private companies and from international organizations as well as relevant news items over the last decade. Furthermore, a search and review of national and international studies of the mining sector was performed. This made it possible to characterize the past and present of the Colombian mining sector. It also provided an initial basis for understanding what the critical issues for the future of the mining sector in Colombia might be. The understanding obtained from the review made it possible to create a set of questions for a semistructured questionnaire, that followed from this initial review.

Relevant stakeholders and opinion makers were interviewed. The interview had two purposes. First, it allowed for a "reality" check on the issues and understanding developed during the review of data and other secondary material. Second, it raised new issues and concerns related to the industry. In particular, it provided for the possibility of increasing the diversity of views involved and so making sure that all points of view are covered. Due to the use of a semi-structured interview, the different responses from the interviews could be compared and contrasted. In total,58people were interviewed, including private-sector mining experts, managers from the private sector, environmentalists, government officials, academics and consultants.

Table 1. The steps involved in creating the scenarios for the Colombian mining sector.

\begin{tabular}{|c|c|c|}
\hline Phase & Activity & Outcome \\
\hline Overview & Secondary data collection & $\begin{array}{l}\text { Creation of an overview of the current state of the } \\
\text { Colombian mining sector, including stakeholders, } \\
\text { economic and social impacts, current and past issues } \\
\text { and conflicts, government initiatives, etc. }\end{array}$ \\
\hline Interview & $\begin{array}{l}\text { Interviewing diverse range of selected stakeholders } \\
\text { in the Colombian mining industry }\end{array}$ & $\begin{array}{l}\text { Diverse inputs to the formation of an initial } \\
\text { understanding of the current main issues and main } \\
\text { future concerns for the mining industry }\end{array}$ \\
\hline Workshop I & $\begin{array}{l}\text { Identifying variables and classifying these variables } \\
\text { as certain or uncertain }\end{array}$ & $\begin{array}{l}\text { A relatively large set of relevant variables (concepts) } \\
\text { for the mining sector, split into two groups. } \\
\text { Verification of the issues in the sector }\end{array}$ \\
\hline Workshop II & $\begin{array}{l}\text { Establishing the importance and influence of the } \\
\text { selected variables }\end{array}$ & $\begin{array}{l}\text { A list of the most influential variables, which will } \\
\text { provide the basis for the scenario development }\end{array}$ \\
\hline Workshop III & $\begin{array}{l}\text { Selecting the combination of events and assigning } \\
\text { probabilities to them } \\
\text { Selecting the events that create the backbone of the } \\
\text { scenarios, based on the assigned probabilities and } \\
\text { the outline of a story for each scenario }\end{array}$ & $\begin{array}{l}\text { A (large) set of connected events organized in } \\
\text { a timeline, each with a probability } \\
\text { Three scenario outlines, based on consecutive } \\
\text { events. Some basic story elements and discussion of } \\
\text { potential policy options. }\end{array}$ \\
\hline Panel of experts & $\begin{array}{l}\text { Panel discussion with recognized experts in the } \\
\text { Colombian mining industry }\end{array}$ & $\begin{array}{l}\text { Discussion of possible unexpected events and } \\
\text { further development of the stories around each } \\
\text { scenario }\end{array}$ \\
\hline Writing of scenarios & $\begin{array}{l}\text { Development of the stories underlying the scenarios } \\
\text { and selected major events. }\end{array}$ & A set of three developed and documented scenarios \\
\hline
\end{tabular}




\subsubsection{Workshops}

We describe here the three workshops that took place with the stakeholders, the method and the outcome of each workshop.

\subsubsection{Workshop 1: Identifying key variables. The first} workshop lasted three and a half hours and was aimed at identifying key variables for the evolution of the sector as well asa classification of selected variables. One group of key drivers was designated as "certain", i.e. events that it was generally agreed would take place, whatever happened, over the next 20 years. This included e.g., the impact of climate change and a possible consolidation of mining industries. The second group of drivers was designated as "variable", being seen as uncertain. A variable can be uncertain in two different dimensions. First, "Will a particular event take place? "For example, will there be another Black Monday or not. The second dimension of uncertainty is that the event will take place but it is impossible to say when; it could happen sooner or later, e.g. "When will the price recover? "Furthermore, the variables were ranked in their perceived importance for the sector, e.g. corruption was seen as more important than new infra-structure for the development of the mining sector.

Those participating in this workshop were the third group mentioned above, together with the coordination group.The underlying method employed was a combination of structured approaches known as "Safari" and "World Cafe" [51,52]. These methodologies allow for a more structured, focused, and intense process, which was suitably efficient for carrying out the collective work. These methods also make sure that all participants are involved in the process, making facilitation easier and ensuring that all their available knowledge and expertise are used in the process. The workshop identified, at this stage, a total of ten variables that were seen as important for the evolution of the mining sector in Colombia.

3.2.2.2. The second workshop: establishing certainties and uncertainties. The second workshop followed two months later and continued the work from the first and lasted two days. The number of variables from the first workshop needed to be reduced to make it feasible to create a set of scenarios. While there are some certainties in all the scenarios, by definition, not all of them might be equally relevant or influential. For uncertainties, we need to get to consensus about which are the most relevant and influential, as it would create too many combinations of possible developments if they were all included. Participants in the workshop were asked to identify direct influences among uncertain variables using a cross-impact matrix [53]. The structural analysis ranked variables according to their perceived importance for the sector. The consensus was that the most influential variables were stability, legal coherence and institutional coordination along with conflicts over control and land use management. Table 2 lists the final set of uncertainties (left column). We then group this set of nine uncertainties into five broad categories that make it possible to represent them in a limited number of scenarios (shown in the right-side column in Table 2).

We used a structural analysis technique, known as cross-impact analysis, to be able to establish which of the uncertainties were the most influential [53]. The evaluation is done qualitatively, evaluating oneway causality among the variables where, in the matrix, a value ranges from zero, which implies no influence, to three, indicating a strong influence. The sums of the rows and columns of each variable in the cross-impact matrix provide a set of two numbers that establish how influenced the variable is by other variables and how much it influence others [53]. For the full matrix see the Table (A1) in Appendix 2 .

Table 2. A list of the final set of uncertainties.

\begin{tabular}{ll}
\hline Identified uncertainties/issues & Final group of uncertainties \\
\hline - Stability, legal coherence and coordination & $\bullet$ Institutions \\
- Illegality culture (corruption, fraud, terrorism) & \\
- Strengthening institutions in the mining sector & \\
- Ability and capacity for monitoring and law enforcement & \\
- Infrastructure (railways, energy resources) & $\bullet$ Economic development \\
- Knowledge about available natural resources & • Community attitudes towards mining \\
- Conflicts over control, land use management & • Environmental sustainability \\
- Connection between the mining and environmental sector & $\bullet$ Mining production and revenues \\
\hline
\end{tabular}




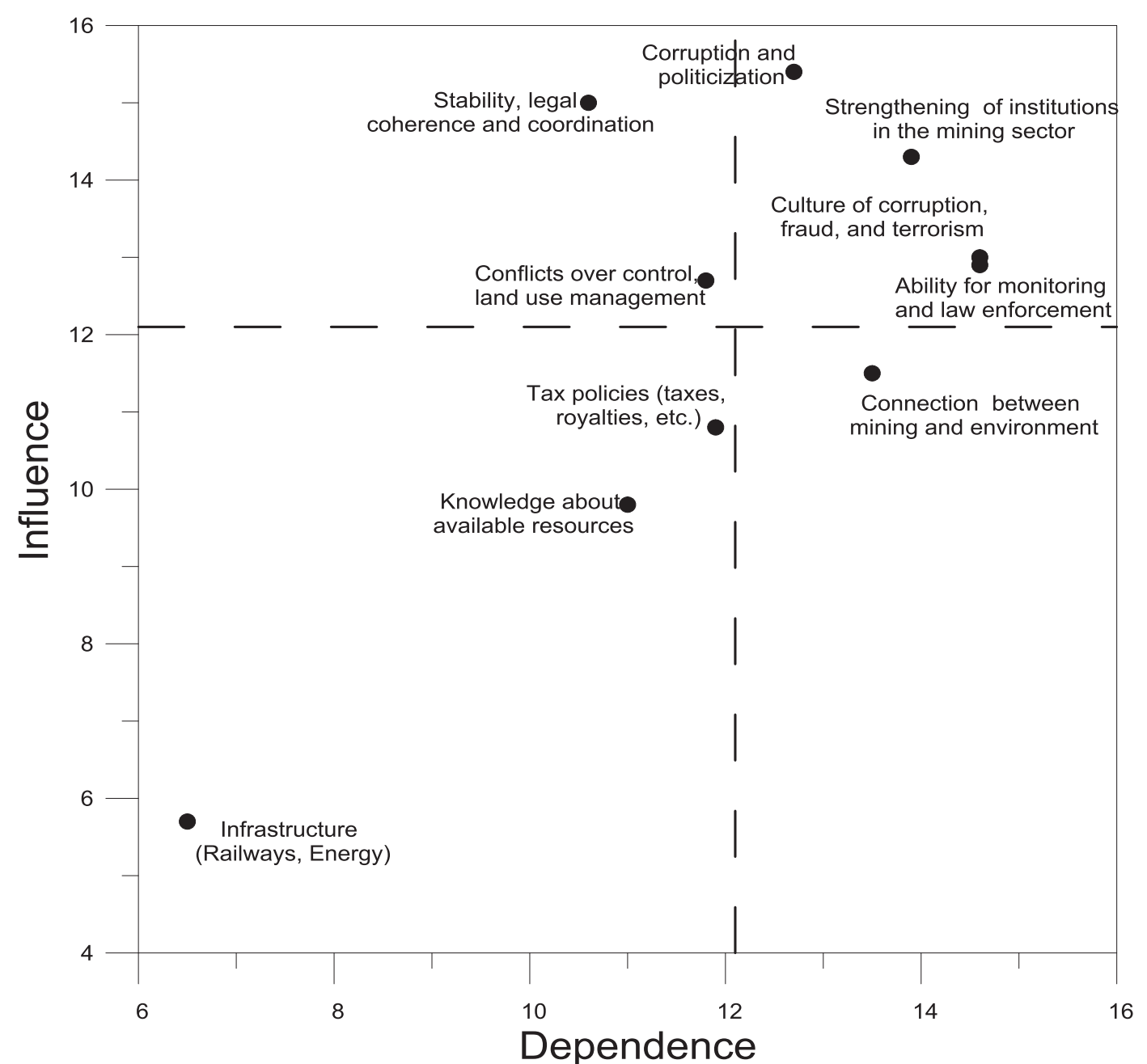

Fig. 2. Scatter plot of the main uncertain variables, showing their influence over the other variables (y-axis) versus how much they are influenced by other variables ( $x$-axis).

The results from the exercise for the nine variables are shown in the scatter plot in Fig. 2. The diagram represents the aggregated values of the variables. Variables in the upper left quadrant are variables that are not influenced much by other variables (low value on the $x$-axis) while they have a large influence on other variables (high values on the y-axis). The opposite is true for the variables in the lower right quadrant: they do not influence other variables (low value on the y-axis) but are themselves highly influenced by other variables (high value on the $x$ axis). While variables in the upper right quadrant are "connectors", influenced and influencing other variables, conversely, variables in the lower left quadrant are more or less isolated in the system. When we are choosing which uncertain variables the scenario should be built around, the variables in the upper quadrants are more relevant as they are likely to have much more influence on the development across the sector. However, the relative strength of variables cannot be seen in Fig. 2, but can be seen in the Appendix 2 where the final cross impact matrix is shown.

As we can see in Fig. 2, the variables that seem to have little influence are Infrastructure followed by Knowledge about the available natural resources and Tax policies. We can conclude that these are the variables that have the least influence on the future development of the sector. The variables with the most influence are Stability, legal coherence and coordination as along with Conflicts and control over land use.

Based on the matrix (Appendix 2), it is also possible to visualize the causal influences among the variables, providing a systemic view of the interconnections among the variables that drive the sector. In this case, we have chosen only the strongest links between the variables, as shown in Fig. 3, where the causal link is indicated with an arrow. As indicated in Fig. 3, we can cluster the variables into five groups. One representing the mining activities 


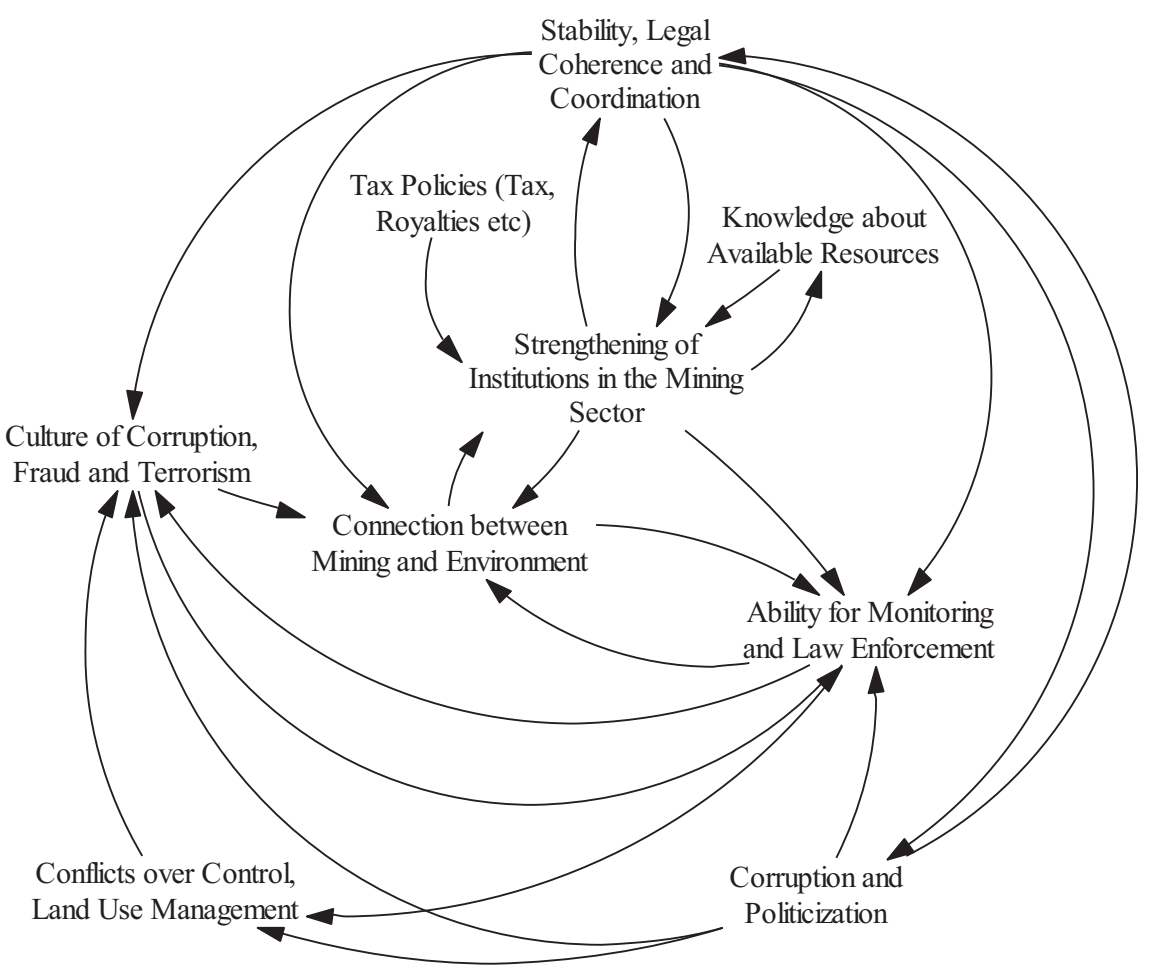

Fig. 3. Causal relationships between the variables with the highest influence, from the cross-impact matrix shown in Appendix 2.

and revenues, one dealing with the environment, another with socio economic factors, one centered on the public institutions, and finally,one with the issues that are outside the sector.

\subsubsection{The third workshop: Identifying scenarios}

The third workshop, following two months later and lasting one and a half day, contained three parts. In the first part of the third workshop, possible futures were explored, from the present to 2032, by combining the possible states of the driving variables. Through morphological analysis [53], we identified diverse combinations of possible states of these key variables and selected those most consistent with the views of the workshop participants. To achieve this, a combinatorial tree analysis was developed for all the possible states of the key variables, and conditional probabilities were assigned to them. In the tree, the nodes correspond to the driving variables and each branch corresponds to a possible value of that variable in the future. The workshop participants assigned the probabilities, so they are "subjective", but agreed probabilities from the participants. To deal with the subjectivity, participants answered with "high","medium", or "low" as estimates of the probabilities, to which quantitative values were assigned afterwards.

The second part of the workshop aimed to reduce the set of combinations based on the tree of probabilities developed in the second workshop. We focused on combinations with the highest probability. From the beginning of the workshop it was the intention that we should end with a maximum of four scenarios as research and experience have shown that if the number of scenarios becomes larger than four, then it is difficult to distinguish and communicate them [29]. After discussion in the group, the "routes" were selected, i.e. a set of events from the initial node to the final branch. These were the three sets of "routes" that had the highest conditional probability among the many possible paths through the tree. After a further (longer) discussion it was decided that adding more sets of "routes"would not create further value. This led to the decision that there would be just three scenarios, each based on one of the sets of events that created a path through the tree.

In the final part of the third workshop we started to outline the scenarios, in terms of events and issues that would create the backbone of the stories that would illustrate each scenario. There was also a discussion of various strategies, each corresponding to specific policies, e.g. a change of government regulations or major infrastructure construction that might affect the transportation of minerals. The strategic options can be used as potential decisions that can be evaluated in the different scenarios, looking for the most robust set of policies that perform well across all the different scenarios. 
Table 3. Expected changes of key variables for each scenario for 2032 with respect to 2013. An up-arrow means that the variable increased with respect to its 2013 levels, while a down-arrow means that the variable decreased. Horizontal arrows indicate no changes with respectto 2013.

\begin{tabular}{llll}
\hline Variable & \multicolumn{2}{l}{ Changes in 2032 with respect to 2013 } \\
\cline { 2 - 4 } & Wonderful Years & Ups and Downs & Running after Two Hares \\
\hline Quality of institutions & $\uparrow$ & $\leftrightarrow$ & $\leftrightarrow$ \\
Mining rents & $\uparrow$ & $\uparrow$ & $\downarrow$ \\
$\quad$ Mineral production and revenues & $\uparrow$ & $\leftrightarrow$ & $\downarrow$ \\
$\quad$ Economic development & $\uparrow$ & $\downarrow$ & $\downarrow$ \\
Society's attitude towards mining & $\uparrow$ & $\downarrow$ & \\
Communities' perception of mining & $\uparrow$ & $\leftrightarrow$ & $\downarrow$ \\
$\quad$ Transparency and accountability & $\uparrow$ & $\uparrow$ & \\
$\quad$ Social control & $\uparrow$ & $\uparrow$ & $\uparrow$ \\
\hline
\end{tabular}

$\uparrow$ increase, $\downarrow$ decrease, $\leftrightarrow$ unchanged.

\subsubsection{Final expert meeting}

In the final meeting among the expert group, there was a discussion of possible unexpected events that should be included in the scenarios. These included, among others, a sharp drop in the price of gold, a serious accident with great loss of life, and a loss of natural resources that affects the relationship between a local community and mining. The meeting also developed the stories around each scenario further, based on the collected information and the discussions in the previous workshops.

\section{Scenarios}

\subsection{Creating the scenarios}

We used the method outlined above to reach a consensus on possible scenarios for the mining industry in Colombia. The workshops created basic pillars on which to create the scenarios, following broadly the structure outline by [54]. For constructing the final version of the scenarios it is important to make sure that they are (i) have involved the right participants [54] (ii) provide insight into current problems and concerns, i.e. be relevant to the stakeholders, (iii) they have to be internal consistent [29] and (xii) be plausible and surprising [54]. These criteria were covered through the broad involvement of the stakeholders, both from the industry, the regulator and NGOs. We had the users involved directly, i.e. UPME and while the scenarios were plausible they are maybe less surprising.

\subsection{The scenarios}

We create three scenarios, which allow us to capture the main implications of the uncertainties developed in Table 2: institutions, mining production and revenues, environmental sustainability, economic development, and community attitudes towards mining. Using these variables as the main generators of different possible futures allows us to describe possible futures for the Colombian mining sector. All the scenarios start in year 2013 and end by 2032, a twenty-year development, which is a reasonable period due to the time lags in the industry. We provide here a short overview of the stories behind the three scenarios.

The three scenarios are named: The Wonderful Years, With Ups and Downs, and If you run after Two Hares, you will catch neither. Table 3 summarizes the changes of key variables in each scenario.

As can be seen in Table 3, the Wonderful Years scenario involves a world where almost everything goes well: there is a general increase in production and revenues, making mining a financially attractive sector. With new technology, increasing transparency has created an environmentally sustainable sector, which has led to a situation where there is a harmonious relationship with local communities affected by the mining activities and other environmental groups. This is a world where the mining industry has found a stable, sustainable equilibrium that benefits most of the stakeholders in the industry. Including the government, mining companies, and local communities, and which is also promoted via a strengthening of institutions generally, in Colombia. By 2032, institutions are strong and accountable and society rejects corrupt practices. The Colombian Geological Service provides reliable and up-to-date information; environmental and mining laws are coherent, and the potential conflict between them is regulated in a fair and transparent manner. The approval process for new mining projects is simplified, reducing lead times, and mining laws and regulations are enforced. Colombia becomes attractive for investors as a result of this new transparency. Mineral prices have been high during most of the period due to world demand for Colombian raw materials. The high prices has driven the expansion of the mining industry, an industry that adopts the best available 
environmental techniques and practices, and embraces social responsibility. Growth is not limited to the mining industry. Industries that provide resources and services to the mining sector are expanding or newly created, and firms that add value to minerals are growing. Mining improves the living standards of local communities, which, in turn, accept mining projects. The rent from the growing mining industry is well managed and invested efficiently, and as a result, the entire Colombian economy expands.

The contrast is the scenariocalled If you run after Two Hares, you will catch neither. Here we have a world where many, if not most things, have deteriorated. There is no increase in prices of raw materials and production has not picked up. This has had a negative effect on the transparency of the industry. Corruption has increased, many stakeholders, including the local communities, feel that they have had a bad deal as they have seen little benefit from mining, and the environmental situation has worsened. Although there is a bit more social control regarding illegal mining and other violations of the rules, it is not enough to stop the negative spiral that mining is causing. As a result of low prices, the lift we saw in the previous scenario never happens in this world. By 2032, the institutions have not progressed as compared with 2013, but decision makers are less accountable, as there has been no improvement in the transparency and enforcement of regulations and laws. A long period of low prices has followed the expansion cycle for minerals that ended in the early 2010s. This, combined with costly barriers to entry into the Colombian mining sector, delays in project development, and uncertainty about the application of regulation makes Colombia unattractive for investors. New exploration and development are stagnant, and most of the production comes from mines that were already operating by 2013. Informal and illegal mining continues in many parts of the country because regulation and enforcement have failed. The environmental situation relating to mining has not improved significantly over the last twenty years and environment regulation and enforcement is still relatively lax. Some mining leases are not renewed and environmental liabilities from abandoned mining operations increase, without any effort to allocate responsibility or enforce clean-up. Although there is increased social control, communities are not consulted on decisions that directly affect them, further increasing the conflict between the mining sector and local communities. The tax contribution from the mining sector to GDP is below the 2013 levels, as there is no new activity and the existing mines have declining output. Unemployment inthe sector is high, and general economic growth is low, as reflected in the low raw material prices. There have been several unsuccessful attempts to increase government income from the mining sector in order to finance public spending.Rents from the mining sector are poorly managed and invested, and the contribution of mining to local and national development is lower than it was in 2013.

In the remaining scenario, Ups and Downs, mineral prices increase, which should provide some benefits for all the stakeholders. However, transparency is not improved and there is no successful attempt to increase the environmental sustainability of the mining sector. This results in a situation where local communities feel that they are not getting any share of the new prosperity that the increased prices have created. Neither in terms of economic development, nor from an environmental point of view as pollution has not improved because corruption has not declined. By 2032, in this scenario, there is still corruption and a lack of coordination among mining institutions. However, the accountability of decision makers remains unchanged and the society is less tolerant of corruption than was the case in 2013. Despite the delays and barriers to development of mining projects in Colombia, mineral prices are high, and new profitable projects are being established. Government income from the mining sector increases following the increased activity; however, the rent is not well managed by the central government and does not benefit other economic sectors. At the regional level, weak institutions and corruption squander mining rents, hindering the development of the mining regions. The programs for reducing informal and illegal mines have had limited success, and informal mining continues. Although there are more environmental controls than in 2013, mining companies tend to comply with standards only minimally.No efforts are made to develop or adopt new technologies for preventing or mitigating the environmental impacts from mining. Social responsibility programs are small and out of touch with the needs of communities. As a result of environmental impacts and lack of community engagement, by 2032, the public image of mining is as negative as it was in 2013.

The three scenarios described above consider gradual and internally-consistent changes in the operating conditions within the mining sector. We know that when we develop scenarios, hardly ever will any of them actually become a reality. However, for the use of the scenarios this is not an issue, as the main use is for testing how robust and desirable 
policies are across the various scenarios. This allows us to understand the shortcomings of current and potential future policies, and thus have opportunities to improve them.

In the following section we discuss the long-term strategies for the Colombian mining sector that were developed, taking the risks of unforeseen events into account, in order to reach the most robust scenarios.

\section{Long-term strategies for the Colombian mining sector}

Policies and strategies for the mining sector in Colombia could have a number of specific objectives, such as:to maximize the rents for the government, as it has been discussed by e.g. [55]; be environmentally sustainable.e.g. [56] for an overview and [57] for an example involving gold; provide incentives for national and international firms to invest in the sector,for a discussion see e.g. [58]; increase the local influence, for a discussion see e.g. [59] and [60]; provide transparency, etc. However, any set of policies that will be implemented needs to share some characteristics, of which the most important is to be able to evolve and respond to new information and developments in the sector.

Following discussion of the scenarios there was a further discussion of what policies would need to be implemented to provide a positive impact on the mining sector, given the current situation and the insights obtained from the three scenarios. That is, what policies would allow the government to achieve some of the objectives mentioned above, and generally nudge the mining sector to become a noncontroversial and contributing factor to the economic development of Colombia?

Currently, some of the strategies have already been proposed $(\mathrm{P})$, and even partially implemented $(\mathrm{PI})$, while others are new $(\mathrm{N})$. The strategies are grouped by topics, in order to provide an overview and focus on the fundamental insights and results of discussions from the workshop.

Social impact $(P)$ : Set up policies that allow for positive impacts from mining on the development of the communities where mining is taking place. To monitor these impacts, it is necessary to improve the social indicators of development and production in connection with mining in order to be able to track, in specific cases, whether or not there is progress [60]. This is also linked to the monitoring the sustainability of the local operations [50]. It will be important to monitor the social, sustainable and economic impact of mining on local communities, not only at a regional or national level. It is understood the need to bring net benefit to the local communities to ensure that there is an acceptance of the mining operations [61].The short-term option for archiving this would be to change the distribution of royalties so that territories directly affected have real benefit from mining and from the value chains of the mining industry. The long-term and more sustainable solution would be to strengthen the regional presence of the mining institutions so that they are closely connected with the area where mining takes place.However, this is a complex area as experience from other places has shown, see e.g. [62] and [63]. Despite the potential problems this is as seen from the outcome in the analysis shown in Fig. 2, conflicts over control, land use management, one of the most effective points to focus on.

Trade and supply chains $(\mathrm{P})$ : The first step would be to understand the mineral trade routes that pass through Colombia and identify the business opportunities relating to these routes. This would include an understanding of the details of the global supply chains for different minerals and an exploration of available opportunities. Can Colombia add more value to any of the steps in the supply chain, e.g. by increasing the value added to the minerals instead of just exporting raw materials? This would enable the creation of vertical and horizontal linkages in the mining sector, e.g. the establishment of a strong service sector that would have the possibility of expanding also beyond Colombia.This is, however, a complex issue, as added value can be meet with e.g. higher tariffs when it is exported [50]. In the longer term it might be an advantageforthe government to become directly involved as a partner, perhaps through a state mining company to facilitate this process.Furthermore, there is an increasing focus on sustainable supply chain management across the whole value chain, Colombia might encourage the mining companies to develop this practice, not only to obtain a bigger role in the global supply chain, but also to help regarding the previous discussed social impact [64].

Administration $(\mathrm{N})$ : With regard to administrative procedures, the approval process for mining projects should be simplified and channeled via a "single window". This is something which could be done within a relative short-time horizon. Different government offices must be coordinated and aligned according to public sector policies. It is a task for the national government to create a legal framework for the consistency and coherence among related government institutions, including the mining and environmental component, e.g. as is the case in Germany for large scale infra-structure projects [65]. There is currently globally focus on 
developing standards for environmental impact assessments, which has been used in a number of countries, e.g. Peru [66]. In the same category, but already in the implementation phase, is a need for more detailed and fully credible knowledge of the ground-level conditions and conditions underground, for the benefit of national and international mining concerns. For this to succeed there needs to be sufficient investment to improve both the quality and quantity of available geological and geophysical information.This implies that the second proposal might take longer time to establish as it might require significant resource.

Integral transparency scheme $(\mathrm{N})$ : In order to increase transparency and facilitate accountability, the Colombian Mining Information System (SIMCO) should be expanded and strengthened. Such expansion should follow the principles of information transparency, e.g. adherence to the Extractive Industries Transparency Initiative. In the short-term an ombudsman for the Colombian mining sector should be established and empowered to empower and formalize citizen oversight. Finally, to improve transparency further, the public sector should adhere to a meritocratic system when filling its positions, another initiative that could be implemented quickly. In the longer term, new contracts for the development of mining projects should include requirements regarding technology transfer issues and technological development in Colombia. The analysis represented in Fig. 2, indicates that the area of corruption and political interference as well as stability, legal coherence and coordination have significant influence on the rest of the mining sector, making this one of the key points to focus on.There is evidence that opening a mine increases corruption in an area [67] and that smaller companies are more likely to participate in corruption when they explore [68], this should be prevented by creating more transparency around new projects and the local decision makers.

Regulation and enforcement (PI): The establishment of regulation schemes for mining-related issues such as environmental permits, and requirements for prior consultation with stakeholders, etc. This ensure that there are opportunities to observe whether the rules are followed, and if necessary flag transgressions. With respect to the environment it is particularly important that consultations take place as mining can have a significant influence on the local environment. The consultation process should be rethought, so that it is the State and not individuals who consult communities on the granting of mining rights. Furthermore, the capacity of mining and environmental authorities for the exercise of control, oversight, and prosecution should be significantly strengthened. This will increase the legitimacy and sovereignty of the State, in the effective control of territory and in their ability to provide public goods and essential services.

Other initiatives $(\mathrm{P})$ : Improve and implement education programs for mining, for all levels from the basic level of education to advanced research programs. However, this should not only include technical education but the whole range from mining impacts on the environment, from its economic aspects through to the social and human impacts.

\section{Concluding remarks}

In this paper, we apply a structured design method to developing scenarios, using what can be seen as a modified version of the classical Godet proposal [53]. Using this method, we have developed a set of scenarios for the Colombian mining industry, which allow us to shed some light on the possible future development of the sector. We have also explored some of the possible strategies that could be used by the Colombian government, for whom the scenarios were developed, to establish a more long-term and sustainable mining sector.

Colombia's mineral production expanded in the 2004-2013 period, during an international context of increasing demand for minerals and metals, particularly in the first part of the period. This global trend in the mining industry is expected to continue in the future, given the projected trends in global GDP growth towards 2030 [69]. Besides growing demand, another factor was the incentives provided to investors by Colombian government offers to investors, which led to an increase in foreign direct investment in mining projects in Colombia.

Colombia's mining sector is not attractive enough for most foreign investors. There are a number of reasons for this such as unclear regulation, and conflicts with local communities, just to mention a few. However, in recent years, different weak points have improved significantly; e.g., the internal conflict that had lasted more than fifty years. Other South American countries have significantly higher levels of foreign investment directed to the extraction of minerals, than does Colombia [14]. This project has tried to help understand what the future might hold for the Colombian mining sector, and what factors might prevent the Colombian mining sector from reaching its full potential. In collaboration with the main stakeholders we have identified, via the scenarios, the domestic factors that will affect Colombia's ability to attract foreign investment.

Previous scenarios for the mining and extraction industry indicate that global economic performance is 
a worry.A number of internal and regional issues arise from communities that are directly or indirectly affected by mining activity, changing technology, and environmental concerns; these factors, together with regional politics,all play an important role (e.g.[70,71]. This is also confirmed in this study, where community attitudes towards mining and environmental sustainability are among the most important uncertainties that will affect the development of Colombia's minerals and extraction industry over the next 20 years. Moreover, the study identified three other key uncertainties that might be central for the next two decades: quality of institutions (transparency), economic development, and social control. These six variables were the basis for the construction of the scenarios presented in this paper.

Many of the problems that we have highlighted here are not unique to Colombia, e.g. the problematic issues facing the local population, pollution, how the government can capture value from the process while still ensuring foreign investments. Other countries, in a similar situation, i.e. having substantial mineral reserves but are not critical dependent on them, will benefit from a similar process. While many of the issue will be similar, it is also likely that there will be specific national characteristics that will make at least some of the conclusions drawn her different.

Scenarios are subjective, their construction depends heavily on the method, and the people involved in developing them. In other words, we have not developed the perfect scenarios for Colombia's mining sector, as nobody can. We have based the scenarios on the available data in the literature and in the planning unit UPME, combined with a significant number of experts and other stakeholders in the industry, to create a set of credible and possible futures for the mining sector. The true value of the scenarios developed here can only be accessed in the longer term, if they help in shaping the policies of the Colombian mining sector. The scenarios described here has been used as the basis for a detailed analysis using simulation, to be able to understand the qualitative influence on the different stakeholders in the scenarios [72].

\section{Conflicts of interest}

None declared.

\section{Ethical statement}

Authors state that the research was conducted according to ethical standards.

\section{Funding body}

UPME (Unidad de Planeamiento Minero Energética) [contract number C003-2013], called "Construction of long-term mining scenarios for Colombia as input for the mining development plan considering the economic, social and environmental dimensions".

\section{Acknowledgements}

This work was supported by the UPME (Unidad de Planeamiento Minero Energética) [contract number C003-2013], called "Construction of longterm mining scenarios for Colombia as input for the mining development plan considering the economic, social and environmental dimensions" (translated from Spanish). The contents of this publication are the sole responsibility of the authors.

\section{Appendix.}

\section{Appendix 1}

List of organizations that was represented in the scenario development process. Note that there can be more than one participant from an organization.

Workshop Participant

Universidad Nacional de Colombia

consulate of Australia

ARGOS

Nausan Corp

Universidad de los Andes

Sector de la Minería a Gran Escala - SMGE

Agencia Nacional de Minería - ANM

ASOGRAVAS

Unidad de Planeación Minero Energética - UPME

Nausan Corp

Autoridad Nacional de Licencias Ambientales

Ministerio de Minas y Energia

Sector de la Minería a Gran Escala - SMGE

ANDI

AngloGold Ashanti

Minas Paz del Río SA

Angencia Nacional de Minería

Logemin SA

Instituto Humboldt

New Mexico Institute of Mining and Technology

Departamento Nacional de Planeación - DNP

Independent mining consultants

Termotasajero SA ESP

Gemexco

AngloGold Ashanti

Cerromatoso

Nausan Corp

Gmaslab consultores

Colciencias

Minas Paz del Río SA

Consulate of Australia

Sector de la Minería a Gran Escala - SMGE

ASOGRAVAS 
Appendix Table A1: The average of the cross-impact matrices across the groups.

\begin{tabular}{|c|c|c|c|c|c|c|c|c|c|c|c|}
\hline & $\begin{array}{l}\text { Stability, legal } \\
\text { coherence } \\
\text { and } \\
\text { coordination }\end{array}$ & $\begin{array}{l}\text { Knowledge } \\
\text { about } \\
\text { available } \\
\text { resources }\end{array}$ & $\begin{array}{l}\text { Conflicts over } \\
\text { control, land } \\
\text { use } \\
\text { management }\end{array}$ & $\begin{array}{l}\text { Tax policies } \\
\text { (taxes, } \\
\text { royalties, } \\
\text { etc.) }\end{array}$ & $\begin{array}{l}\text { Corruption } \\
\text { and } \\
\text { politicization }\end{array}$ & $\begin{array}{l}\text { Connection } \\
\text { between } \\
\text { mining and } \\
\text { environment }\end{array}$ & $\begin{array}{l}\text { Culture of } \\
\text { corruption, } \\
\text { fraud, and } \\
\text { terrorism }\end{array}$ & $\begin{array}{l}\text { Strengthening } \\
\text { Of institution } \\
\text { in the mining } \\
\text { sector }\end{array}$ & $\begin{array}{l}\text { Infrastructure } \\
\text { (railways, } \\
\text { energy) }\end{array}$ & $\begin{array}{l}\text { Ability for } \\
\text { monitoring } \\
\text { and law } \\
\text { enforcement }\end{array}$ & $\begin{array}{l}\text { How } \\
\text { Influential } \\
\text { are the } \\
\text { variables }\end{array}$ \\
\hline $\begin{array}{l}\text { Stability, legal } \\
\text { coherence and } \\
\text { coordination }\end{array}$ & & 0.6 & 1.7 & 1.8 & 2.0 & 2.1 & 2.0 & 1.9 & 0.8 & 2.1 & 15.0 \\
\hline $\begin{array}{l}\text { Knowledge about } \\
\text { available resources }\end{array}$ & 0.4 & & 1.0 & 1.0 & 1.2 & 1.0 & 1.4 & 1.8 & 1.2 & 0.8 & 9.8 \\
\hline $\begin{array}{l}\text { Conflicts over } \\
\text { control, land use } \\
\text { management }\end{array}$ & 1.5 & 1.7 & & 1.0 & 1.8 & 1.5 & 2.1 & 1.2 & 0.6 & 1.3 & 12.7 \\
\hline $\begin{array}{l}\text { Tax policies (taxes, } \\
\text { royalties, etc.) }\end{array}$ & 1.3 & 1.1 & 1.0 & & 1.5 & 0.4 & 1.6 & 1.8 & 1.1 & 1.0 & 10.8 \\
\hline $\begin{array}{l}\text { Corruption and } \\
\text { politicization }\end{array}$ & 2.1 & 0.7 & 2.2 & 1.8 & & 1.1 & 2.5 & 1.7 & 1.0 & 2.3 & 15.4 \\
\hline $\begin{array}{l}\text { Connection } \\
\text { between mining } \\
\text { and environment }\end{array}$ & 1.0 & 1.8 & 1.5 & 1.1 & 0.9 & & 1.1 & 1.8 & 0.4 & 1.9 & 11.5 \\
\hline $\begin{array}{l}\text { Culture of } \\
\text { Corruption, fraud, } \\
\text { and terrorism }\end{array}$ & 0.8 & 1.4 & 1.1 & 1.5 & 1.6 & 2.2 & & 1.7 & 0.8 & 1.9 & 13.0 \\
\hline $\begin{array}{l}\text { Strengthening } \\
\text { Of institution in the } \\
\text { mining sector }\end{array}$ & 1.9 & 2.0 & 1.1 & 1.5 & 1.4 & 2.2 & 1.4 & & 0.4 & 2.4 & 14.3 \\
\hline $\begin{array}{l}\text { Infrastructure } \\
\text { (railways, energy) }\end{array}$ & 0.2 & 0.6 & 0.7 & 0.9 & 0.5 & 1.1 & 0.6 & 0.2 & & 0.9 & 5.7 \\
\hline $\begin{array}{l}\text { Ability for } \\
\text { monitoring and law } \\
\text { enforcement }\end{array}$ & 1.4 & 1.1 & 1.5 & 1.3 & 1.8 & 1.9 & 1.9 & 1.8 & 0.2 & & 12.9 \\
\hline $\begin{array}{l}\text { How dependent are } \\
\text { the variables }\end{array}$ & 10.6 & 11.0 & 11.8 & 11.9 & 12.7 & 13.5 & 14.6 & 13.9 & 6.5 & 14.6 & 121.1 \\
\hline
\end{tabular}

\section{References}

[1] International Council on Mining \& Metals. Trends in the mining and metals industry: Mining's contribution to sustainable development. London, UK. 2012.

[2] Malm O. Gold mining as a source of mercury exposure in the Brazilian Amazon. Environmental Research 1998;77(2):73-8.

[3] Goel PK. Water pollution: causes, effects and control. New Age International 2006.

[4] Holden WN. Neoliberal mining amid El Niño induced drought in the Philippines. Journal of Geography and Geology 2013;5(1):58.

[5] Hendryx M, Ahern MM. Relations between health indicators and residential proximity to coal mining in West Virginia. American Journal of Public Health 2008;98(4):669-71.

[6] Urkidi L, Walter M. Dimensions of environmental justice in anti-gold mining movements in Latin America. Geoforum 2011;42(6):683-95.

[7] Palmer MA, Bernhardt ES, Schlesinger WH, Eshleman KN, Foufoula-Georgiou E, Hendryx MS, ..., Wilcock PR. Mountaintop mining consequences. Science 2010;327(5962):148-9.

[8] Muradian R, Martinez-Alier J, Correa H. International capital versus local population: The environmental conflict of the Tambogrande mining project, Peru. Society \&Natural Resources 2003;16(9):775-92.

[9] Bury JT. Livelihoods, mining and peasant protests in the Peruvian Andes. Journal of Latin American Geography 2002; 1(1):1-19.

[10] Nasdaq. Copper. 2016. Retrieved from, Nasdaq.com.

[11] Petermann A, Guzmán JI, Tilton JE. Mining and corruption. Resources Policy 2007:32(3):91-103.

[12] UPME. Boletín Estadístico de Minas y Energía 2012 - 2016. Colombia: Unidad de Planeación Minero Energética, 201 p. Bogotá; 2016.
[13] UPME. Sistema de Información Minero Colombiano SIMCO. 2014. Retrieved from, http://www.simco.gov.co/. [Accessed 10 October 2017].

[14] Cepal. Latin American mining sector: review of current trends and prospects. 2013.

[15] Kalmanovitz S. El impacto económico del conflicto interno colombiano y un escenario de paz. Colombia: Bogotá; 2012.

[16] Bonilla L. Diferencias regionales en la distribución del ingreso en Colombia. Dimensión regional de las desigualdades en Colombia. Colección de Economía Regional Banco de la República; 2011. p. 33-64.

[17] Galvis LA, Meisel A. Persistencia de las desigualdades regionales en Colombia: un análisis espacial. Dimensión regional de las desigualdades en Colombia, 1-32. Colección de Economía Regional Banco de la República; 2011.

[18] Saldarriaga-Isaza A, Arango S, Villegas-Palacio C. The public good dilemma of a non-renewable common resource: a look at the facts of artisanal gold mining. Resources Policy 2013;38(2):224-32.

[19] Banchirigah SM. Challenges with eradicating illegal mining in Ghana: A perspective from the grassroots. Resources Policy 2008;33:29-38.

[20] Molano A. Al tren del oro. El Espectador 3/9/2011. 2011. http://www.elespectador.com/impreso/opinion/columna296689-al-tren-del-oro\#. [Accessed 31 January 2012].

[21] Ali S. Mining dilemma. Alternatives Journal 2009;35:8-11.

[22] Fisher $\mathrm{R}$, Ling $\mathrm{H}$, Natonis $\mathrm{R}$, Hobgen $\mathrm{S}$, Riwu Kaho $\mathrm{N}$, Mudita W, Markus J, Bunga W, Nampa W. Artisanal and small-scale mining and rural livelihood diversification: The case of manganese extraction in West Timor, Indonesia. The Extractive Industries and Society 2019;6(1):229-40.

[23] Sovacool B. The precarious political economy of cobalt: Balancing prosperity, poverty, and brutality in artisanal and industrial mining in the Democratic Republic of the Congo. The Extractive Industries and Society; 2019. 
[24] Rosales A. Statization and denationalization dynamics in Venezuela's artisanal and small scale-large-scale mining interface. Resources Policy 2019;63:101422.

[25] Soetanto R, Dainty AR, Goodier CI, Austin SA. Unravelling the complexity of collective mental models: a method for developing and analysing scenarios in multi-organisational contexts. Futures 2011;43(8):890-907.

[26] Folhes RT, de Aguiar APD, Stoll E, Dalla-Nora EL, Araújo R, Coelho A, Do Canto O. Multi-scale participatory scenario methods and territorial planning in the Brazilian Amazon. Futures 2015;73:86-99.

[27] Lindgren M, Bandhold H. Scenario Planning. London: Palgrave; 2003.

[28] Amer M, Daim TU, Jetter A. A review of scenario planning. Futures 2013;46:23-40.

[29] Wack P. Scenarios: uncharted waters ahead. Harvard Business Review 1985:73-89.

[30] Ringland G. Scenario planning: managing for the future. London, UK: John Wiley \& Sons; 1998.

[31] Hansen J, Sato M, Ruedy R, Lacis A, Oinas V. Global warming in the twenty-first century: An alternative scenario. Proceedings of the National Academy of Sciences 2000; 97(18):9875-80.

[32] Ojoyi M, Mutanga O, Kahinda JM, Odindi J, AbdelRahman EM. Scenario-based approach in dealing with climate change impacts in Central Tanzania. Futures 2017;85: 30-41.

[33] Kahane A. Imagining South Africa's future: how scenarios helped discover common ground. In: Fahey L, \&Randall RM, editors. Learning from the Future. New York: Wiley; 1998. p. 325-33.

[34] Vincent-Lancrin S. Building futures scenarios for universities and higher education: an international approach. Policy Futures in Education 2004;2(2):245-63.

[35] Kharrazi A, Kakuwa M. Scenario projects in Japanese government: Strategic approaches for overcoming psychological and institutional barriers. Futures 2017;86:18-26.

[36] Sadorsky P. Some future scenarios for renewable energy. Futures 2011;43(10):1091-104.

[37] Jetter A, Schweinfort W. Building scenarios with Fuzzy Cognitive Maps: An exploratory study of solar energy. Futures 2011;43(1):52-66.

[38] EWEA. Wind energy scenarios for 2030. 2015. Retrieved from, https://www.ewea.org/fileadmin/files/library/ publications/reports/EWEA-Wind-energy-scenarios-2030. pdf/. [Accessed 24 October 2017].

[39] De Geus AP. Planning as learning. Harvard Business Review 1988;66:70-4.

[40] Greenpeace. Energy [r]evolution. Amsterdam, Netherlands. 2015.

[41] Smith RA, Vesga DR, Cadena AI, Boman U, Larsen E, Dyner I. Energy scenarios for Colombia: process and content. Futures 2005;37(1):1-17.

[42] Koch H, Kaltofen M, Grünewald U, Messner F, Karkuschke M, Zwirner O, Schramm M. Scenarios of water resources management in the Lower Lusatian mining district, Germany. Ecological Engineering 2005; 24(1):49-57.

[43] Tuusjärvi M, Mäenpää I, Vuori S, Eilu P, Kihlman S, Koskela S. Metal mining industry in Finland-Development scenarios to 2030. Journal of Cleaner Production 2014;84: 271-80.

[44] Pokhrel LR, Dubey B. Global scenarios of metal mining, environmental repercussions, public policies, and sustainability: a review. Critical Reviews in Environmental Science and Technology 2013;43(21):2352-88.
[45] Ratcliffe J. Scenario planning: strategic interviews and conversations. foresight 2002;4(1):19-30.

[46] Nygrén NA. Scenario workshops as a tool for participatory planning in a case of lake management. Futures 2019;107: 29-44.

[47] Rikkonen P, Kaivo-oja J, Aakkula J. Delphi expert panels in the scenario-based strategic planning of agriculture. Foresight 2006;8(1):66-81.

[48] Tompkins EL, Few R, Brown K. Scenario-based stakeholder engagement: incorporating stakeholders preferences into coastal planning for climate change. Journal of environmental management 2008;88(4):1580-92.

[49] Freeth R, Drimie S. Participatory scenario planning: from scenario 'stakeholders' to scenario 'owners'. Environment: Science and Policy for Sustainable Development 2016;58(4): $32-43$.

[50] Azapagic A. Developing a framework for sustainable development indicators for the mining and minerals industry. Journal of cleaner production 2004;12(6):639-62.

[51] Schieffer A, Isaacs D, Gyllenpalm B. The world café: Part one. World Business Academy; 2004. http://www. theworldcafe.com/wp-content/uploads/2015/07/WorldCafe. pdf/. [Accessed 10 October 2017].

[52] Elliott J, Heesterbeek S, Lukensmeyer CJ, Slocum N. Participatory methods toolkit. A practitioner's manual. viWTA; 2005.

[53] Godet M, Durance P. Prospectiva Estratégica: problemas y métodos. Paris: Godet. Cuad LIPSOR; 2007. p. 105.

[54] Schwartz P. The art of the long view: planning for the future in an uncertain world. Crown Business; 2012

[55] Ergas H, Harrison M, Pincus J. Some economics of mining taxation. Economic Papers: A journal of applied economics and policy 2010;29(4):369-83

[56] Laurence D. Establishing a sustainable mining operation: an overview. Journal of Cleaner Production 2011;19(2-3):278-84.

[57] Mudd GM. Global trends in gold mining: Towards quantifying environmental and resource sustainability. Resources Policy 2007;32(1-2):42-56.

[58] Mitchell P. Taxation and investment issues in mining. Advancing the EITI in the Mining Sector: A Consultation with Stakeholders. Oslo: Extractive Industries Transparency Initiative; 2009. p. 27-31.

[59] Bebbington A, Hinojosa L, Bebbington DH, Burneo ML, Warnaars X. Contention and ambiguity: Mining and the possibilities of development. Development and change 2008 39(6):887-914.

[60] Kemp D. Mining and community development: problems and possibilities of local-level practice. Community Development Journal 2009;45(2):198-218.

[61] Veiga MM, Scoble M, McAllister ML. Mining with communities. Natural Resources Forum 2001, August;25(3):191-202.

[62] Hamann R, Kapelus P, Sonnenberg D, Mackenzie A, Hollesen P. Local governance as a complex system: Lessons from mining in South Africa, Mali and Zambia. Journal of Corporate Citizenship 2005;(18):61-73.

[63] Cheshire L, Everingham JA, Lawrence G. Governing the impacts of mining and the impacts of mining governance: Challenges for rural and regional local governments in Australia. Journal of Rural Studies 2014:36:330-9.

[64] Sauer PC, Seuring S. Sustainable supply chain management for minerals. Journal of Cleaner Production 2017;151:235-49.

[65] Schütte P. Planning and approval of large scale infrastructure projects in Germany. Journal for European Environmental \& Planning Law 2005;2(5):384-92.

[66] Li F. Documenting accountability: environmental impact assessment in a Peruvian mining project. PoLAR: Political and Legal Anthropology Review 2009;32(2):218-36. 
[67] Knutsen CH, Kotsadam A, Olsen EH, Wig T. Mining and local corruption in Africa. American Journal of Political Science 2017;61(2):320-34.

[68] Dougherty ML. By the gun or by the bribe: firm size, environmental governance and corruption among mining companies in Guatemala. Chr. Michelsen Institute; 2015. p. 17. U4 Issue Paper.

[69] World Economic Forum. What will global GDP look like in 2030?. 2016. https://www.weforum.org/agenda/2016/02/ what-will-global-gdp-look-like-in-2030/. [Accessed 10 October 2017].
[70] MMSD. Learning from the future alternative scenarios for the North American mining and minerals industry. Manitoba, Canada: Winnipeg; 2002.

[71] World Economic Forum. Mining and Metal Scenarios to 2030. Geneva, Switzerland. 2010.

[72] Arango S, Jaramillo P, Olay Y, Smith R, Restrepo OJ, Saldarriaga-Isaza A, Aria-Gaviria J, Parra JP. Simulating mining policies in developing countries: the case of Colombia. SocioEconomic Planning Science 2017;30(6):99-113. 